\title{
PAPAYA SEEDLING PRODUCTION UNDER DIFFERENT SHADING LEVELS AND SUBSTRATE COMPOSITIONS
}

\author{
Josiane S. Salles $^{1^{*}}$, Alexandre H. F. de Lima ${ }^{1}$, Edilson Costa ${ }^{1}$, Eliana D. C. Binotti ${ }^{1}$, \\ Flávio F. da S. Binotti ${ }^{1}$
}

${ }^{1 *}$ Corresponding author. Universidade Estadual de Mato Grosso do Sul/ Cassilândia - MS, Brasil.

E-mail: josi_souzasalles@hotmail.com | ORCID ID: https://orcid.org/0000-0001-9345-4834

\section{KEYWORDS}

Carica papaya L., plant ambience, cattle manure, vermiculite.

\begin{abstract}
Papaya is characterized as one of the most important crops in Brazil. Thus, good quality seedlings are essential for formation of orchards in agricultural production. This study aimed to evaluate shading levels and substrate compositions for production of papaya seedlings. Growing environments were evaluated with $0,18,35$, and $50 \%$ shading and substrates from combinations (\%) of hillside soil (HS), cattle manure (CM), Bioplant ${ }^{\mathbb{B}}$ (BP), washed fine sand (FS), and super fine-grained vermiculite (FV). As there was no replication for the growing environments, the group of experiments were analyzed using a $4 \times 4$ factorial arrangement (4 shades $\times 4$ substrates), with five replications. Growth and biometric relationships were analyzed. Substrates consisting of $30 \% \mathrm{HS}+15 \% \mathrm{CM}+$ $20 \% \mathrm{BP}+20 \% \mathrm{FS}+15 \% \mathrm{FV}$ and $45 \% \mathrm{HS}+0 \% \mathrm{CM}+20 \% \mathrm{BP}+20 \% \mathrm{FS}+15 \% \mathrm{FV}$, as well as environments with 18 and $35 \%$ shading formed seedlings with higher plant heights, diameters, phytomass, and Dickson quality indices. The results showed that substrates with a higher content of hillside soil and lower content of cattle manure, associated with an environment with 18 or $35 \%$ shading, provided high-quality seedlings.
\end{abstract}

\section{INTRODUCTION}

Brazil is a major fruit producer worldwide. However, the state of Mato Grosso do Sul has a low production, lacking for research involving its fruit production chain from seedling production stage. Therefore, there is a need for technical support to local producers in order to increase production in this state (Costa et al., 2010 a).

Seedling formation is carried out using several techniques and technologies to increase seedling quality, especially the use of a protected environment and adequate substrates. Protected environments shelter plants from direct radiation, phytosanitary hazards, heavy rains and winds, enabling production at different times of the year. As substrates support plant growth, they should have suitable chemical and physical properties for proper root and shoot development.

High-quality papaya seedlings for the formation of plants with high genetic potential can ensure the success of fruit production (Albano et al., 2014). Seedling quality is associated with factors such as adequate formation, robust and well-distributed root system, low relationship between shoot and root phytomass, and higher Dickson quality indices (Costa et al., 2015; Arrua et al., 2016; Sanches et al., 2017).
Costa et al. (2010b) performed studies on the formation of papaya seedlings in protected environments, in which monofilament and aluminized screened environments produced seedlings with higher heights and increased leaf numbers throughout the experimental period. Costa et al. (2009) studied different substrates, growing environments, and containers for papaya seedling production and observed that aluminized screen environments, as well as substrates with vermiculite, formed improved quality seedlings.

Additionally, Pereira et al. (2015) studied four sources of organic compost (carnauba straw, sheep manure, carnauba straw + sheep manure, and soil as control) and observed that carnauba straw provided the best results in terms of papaya seedling growth, as soil water retention increased and hence more water and nutrients were available for plants.

In short, favorable conditions are essential for early development and growth of plants, particularly weather effect mitigation and substrate composition, and thus obtain high-quality seedlings. Therefore, this study aimed to evaluate different shading levels and substrate compositions for production papaya seedlings (Carica papaya).

\footnotetext{
${ }^{1}$ Universidade Estadual de Mato Grosso do Sul/ Cassilândia - MS, Brasil. 


\section{MATERIAL AND METHODS}

The experiments with papaya (Carica papaya) seedling formation using four substrate compositions and four shading levels were conducted at the State University of Mato Grosso do Sul (UEMS), Cassilândia University Unit (UUC), which is located in Cassilândia city $\left(19^{\circ} 07^{\prime} 21^{\prime \prime} \mathrm{S}, 51^{\circ} 43^{\prime} 15^{\prime \prime} \mathrm{W}\right.$, and altitude of $\left.516 \mathrm{~m}\right)$. According to Köppen's climate classification, the region presents a rainy tropical climate (Aw) in the summer and dry in the winter (Silva et al., 2010).

Growing environments consisted of 1) open-air environment, with $0 \%$ shading, at full sun (E1);2) screened greenhouse with a wooden structure of $6.00 \mathrm{~m}$ wide $\times 6.00 \mathrm{~m}$ long $\times 2.50 \mathrm{~m}$ high, $90^{\circ}$ inclination closure, full-length monofilament screen, and $18 \%$ shading $\left(\right.$ Sombrite $\left.\left.^{\circledR}\right)(E 2) ; 3\right)$ screened greenhouse with a wooden structure of $6.00 \mathrm{~m}$ wide $\times 6.00 \mathrm{~m}$ long $\times 2.50 \mathrm{~m}$ high, $90^{\circ}$ inclination closure, full-length monofilament screen, and $35 \%$ shading (Sombrite ${ }^{\mathbb{R}}$ ) (E3); and 4) screened greenhouse with a galvanized steel structure of $8.00 \mathrm{~m}$ wide $\times 18.00 \mathrm{~m}$ long $\times 3.50 \mathrm{~m}$ high, $45^{\circ}$ inclination closure, full-length monofilament screen, and $50 \%$ shading $\left(\right.$ Sombrite $\left.{ }^{\circledR}\right)(\mathrm{E} 4)$.

Propagation was carried out using commercial seeds from the variety Formosa. Sowing was conducted on June 29, 2016, using one seed per container at a depth of 2 $\mathrm{cm}$, in $1.8-\mathrm{L}$ polyethylene bags $(15.0 \times 25.0 \mathrm{~cm})$. These containers were filled with substrates (S) from combinations of hillside soil (HS), cattle manure (CM), Bioplant $^{\circledR}$ (BP), washed fine sand (FS), and super finegrained vermiculite (FV), with substrate combinations shown in Table 1.

TABLE 1. Substrates from mixtures at different proportions of slope soil (SS), cattle manure (CM), Bioplant ${ }^{\circledR}(\mathrm{BP})$, washed fine sand (FS), and super fine-grained vermiculite (FV). Cassilândia, MS, 2016.

\begin{tabular}{lccccc}
\hline & Hillside soil (HS) (\%) & $\begin{array}{c}\text { Cattle manure (CM) } \\
(\%)\end{array}$ & Bioplant $^{\circledR}(\mathrm{BP})(\%)$ & $\begin{array}{c}\text { Washed fine sand } \\
(\mathrm{FS})(\%)\end{array}$ & $\begin{array}{c}\text { Super fine-grained } \\
\text { vermiculite (FV) (\%) }\end{array}$ \\
\hline S1 & 0 & 45 & 20 & 20 & 15 \\
S2 & 15 & 30 & 20 & 20 & 15 \\
S3 & 30 & 15 & 20 & 20 & 15 \\
S4 & 45 & 0 & 20 & 20 & 15 \\
\hline
\end{tabular}

$\mathrm{S} 1, \mathrm{~S} 2, \mathrm{~S} 3$, and $\mathrm{S} 4=$ substrates.

Cattle manure was obtained from a local slaughtering house and was composed of corral manure and rumen material. It was composted for 45 days, beginning July 4 and ending August 19, 2015, in a covered place, being turned over and moistened every two days. The hillside soil was collected at the base of the mountains of the region. Vermiculite and washed fine sand were obtained from commercial companies. Hillside soil and cattle manure were chemically characterized, as shown in Tables 2 and 3. Seedlings were watered using a watering can, trying not to soak the substrates and keep their moisture close to field capacity.

TABLE 2. Results of the analysis of the characteristics of cattle manure (CM). Cassilândia, MS, 2016.

\begin{tabular}{|c|c|c|c|c|c|c|c|}
\hline $\mathrm{N}$ & $\mathrm{P}_{2} \mathrm{O}_{5}$ & $\mathrm{~K}_{2} \mathrm{O}$ & $\mathrm{Ca}$ & $\mathrm{Mg}$ & S & $\mathrm{M}-65^{\circ} \mathrm{C}$ & $\mathrm{C}$ \\
\hline 0.9 & 0.3 & 0.1 & 0.3 & 0.1 & 0.2 & 2.0 & 11.0 \\
\hline $\mathrm{Na}$ & $\mathrm{Cu}$ & $\mathrm{Fe}$ & $\mathrm{Mn}$ & $\mathrm{Zn}$ & $\mathrm{C} / \mathrm{N}$ & $\mathrm{pH}$ & OM \\
\hline & & $\mathrm{kg}$ to $\mathrm{nc}$ & 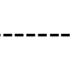 & -- & & $\mathrm{CaCl}_{2}$ & $* * \%$ to natural \\
\hline 624 & 18 & 12103 & 204 & 53 & $12 / 1$ & 5.3 & 20.0 \\
\hline
\end{tabular}

$\mathrm{M}=$ moisture; $\mathrm{OM}=$ organic matter; $\mathrm{C} / \mathrm{N}=$ carbon to nitrogen ratio.

TABLE 3. Results of the analysis of the characteristics of hillside soil (HS). Cassilândia, MS, 2016.

\begin{tabular}{|c|c|c|c|c|c|c|c|c|c|}
\hline $\mathrm{pH}$ & \multicolumn{3}{|c|}{----------cmolc $\mathrm{dm}^{-3}$--------- } & \multicolumn{2}{|c|}{$\mathrm{mg} \mathrm{dm} \mathrm{dm}^{-3}(\mathrm{ppm})$} & \multirow{2}{*}{$\begin{array}{c}\text { cmolc } \\
\text { CEC }\end{array}$} & \multicolumn{3}{|c|}{-------Texture $\left(\mathrm{g} \mathrm{dm}^{-3}\right)$------ } \\
\hline $\mathrm{CaCl}_{2}$ & $\mathrm{Ca}$ & $\mathrm{Mg}$ & $\mathrm{Al}$ & K & $\mathrm{P}(\mathrm{mel})$ & & Clay & Silt & Sand \\
\hline 5.8 & 6.10 & 2.20 & 0.01 & 165 & 1.8 & 11.1 & 110 & 50 & 840 \\
\hline \multicolumn{2}{|c|}{$\mathrm{mg} \mathrm{dm} \mathrm{dm}^{-3}(\mathrm{ppm})$} & \multicolumn{5}{|c|}{-------- $\mathrm{mg} \mathrm{dm}^{-3}$ (ppm), Mehlich 1-------- } & \multicolumn{2}{|c|}{$\mathrm{g} \mathrm{dm}^{-3}$} & $\%$ \\
\hline $\mathrm{S}$ & B & $\mathrm{Cu}$ & $\mathrm{Fe}$ & $\mathrm{Mn}$ & $\mathrm{Zn}$ & $\mathrm{Na}$ & $\mathrm{OM}$ & $\mathrm{OC}$ & $\mathrm{BS}$ \\
\hline 4.8 & 0.24 & 0.4 & 14 & 90.5 & 1.7 & ns & 35.6 & 20.6 & 78.4 \\
\hline
\end{tabular}

$\mathrm{OM}=$ organic matter; $\mathrm{OC}=$ organic carbon; $\mathrm{BS}=$ base saturation. 
Emergence was verified on July 12, 2016, at 13 days after sowing (DAS). The data for analysis of emergence speed index (ESI) and percentage of emergence (PE) were collected from July 12 to August 11, 2016. Plant height (PH) was measured at 45, 52, 59 and 66 days after sowing (DAS). Collar diameter (CD), shoot dry matter (SDM), and root dry matter (RDM) were also measured at 66 days after sowing (DAS). The total dry matter (TDM), the shoot to root system dry matter ratio (SRR), and the Dickson quality index (DQI) were determined from these data.

Seedling height was measured with a ruler $(\mathrm{cm})$ and consisted of the distance from plant collar to its apex, while collar diameter was measured using a digital caliper $(\mathrm{mm})$. The root $(\mathrm{g})$ and shoot $(\mathrm{g})$ dry matter were obtained after drying them in a forced-air circulation oven at $65{ }^{\circ} \mathrm{C}$ until constant weight and measurement on an analytical balance. Total dry matter was obtained by summing the shoot and root dry matter.

Air temperature $\left({ }^{\circ} \mathrm{C}\right)$ and relative air humidity (\%) were monitored in the growing environments using an Instrutemp ITLOG 80 data logger. Photosynthetically active radiation ( $\left.\mu \mathrm{mol} \mathrm{m} \mathrm{m}^{-2} \mathrm{~s}^{-1}\right)$ was measured with the Apogee Instruments (Quantum Flux) MQ 200 apparatus. The data of radiation were collected from July 1, 2016, to September 2, 2016, while temperature and relative air humidity data were collected from July 11, 2016 (Figure 1 and Table 4).

The data were subjected to analysis of variance (Ftest) and means compared by the Scott Knott test at 5\% probability. Each growing environment was considered an experiment because there were no replications. A completely randomized design was used for each growing environment for the evaluation of substrate, with five replications of five seedlings each. Environments were evaluated by the analysis of the group of experiments (Banzatto \& Kronka, 2013) in a 4 x 4 factorial scheme (4 shades $\times 4$ substrates). Emergence percentages were transformed into arcsine square root of $\mathrm{x} / 100$.

\section{RESULTS AND DISCUSSION}

The micrometeorological parameters collected at different shading levels during papaya seedling formation are shown in Table 4 and Figure 1. Air temperature (Figure 1A) and relative air humidity (Figure 1B) are similar at each month of collection in the different shades, as well as the overall mean of the period (Table 4). The intensities of the photosynthetically active radiation (PAR) (Figure 1C) varied as a function of the shading level, where the lower the shading level is, the higher the measured radiation.

The highest shading level $(50 \%)$ presented PAR of $37.9 \%$ in relation to full sun (Table 4), which affected seedling quality in these two environments. The full sun environment $(0 \%$ shading $)$ showed a compromised seedling development, not allowing collecting the data, and hence, this environment was not part of the statistical analysis. Thus, the data analysis considered only the other shades for comparison $(18,35$, and $50 \%)$.

\section{Temperature $\left({ }^{\circ} \mathrm{C}\right)$}

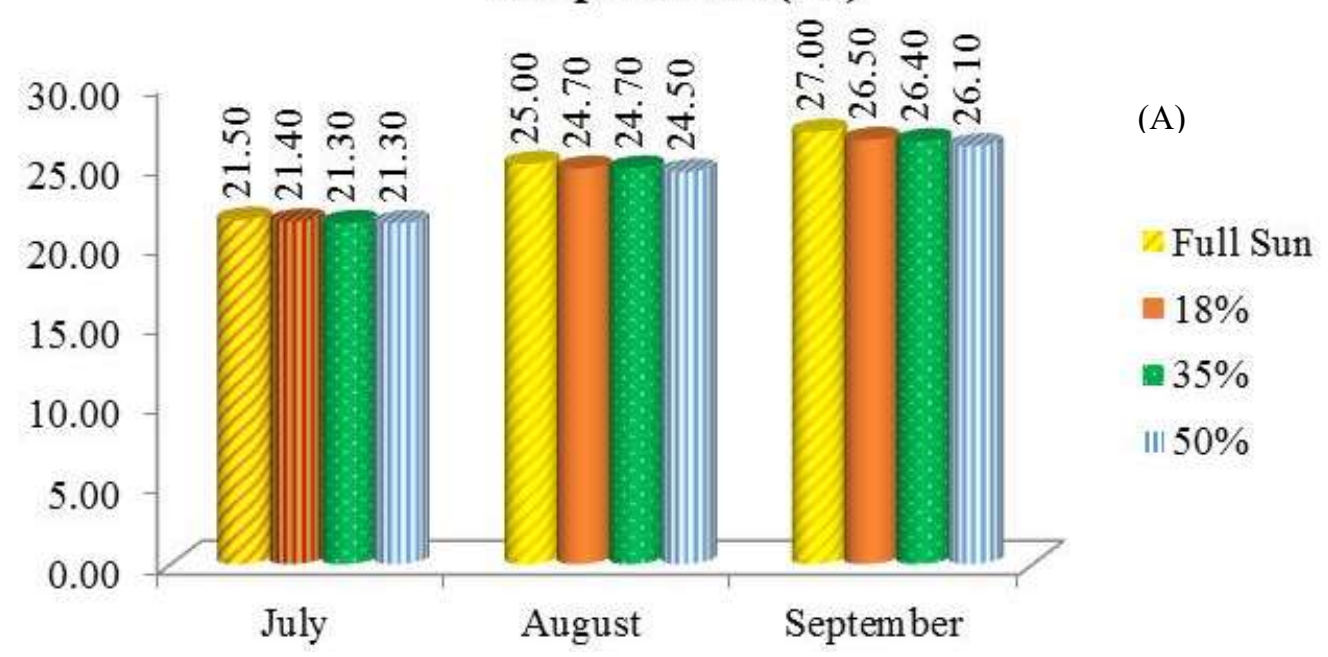




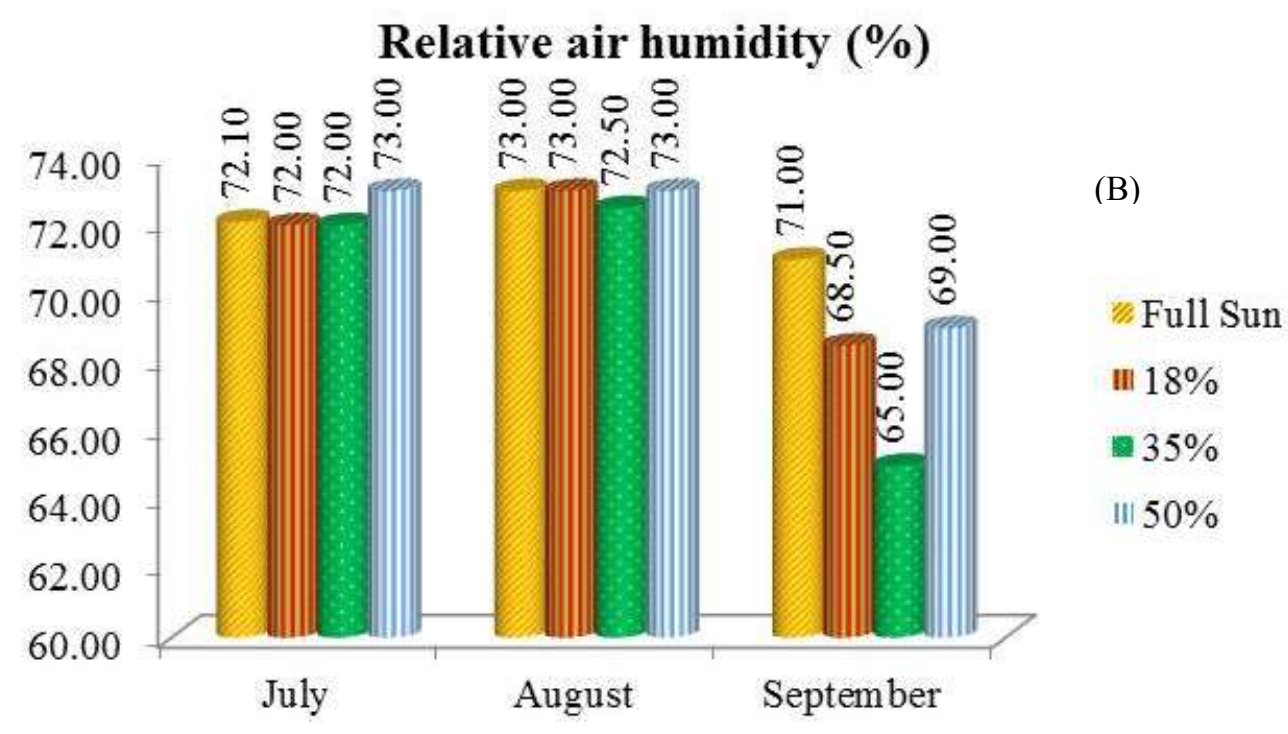

Photosynthetically Active Radiation

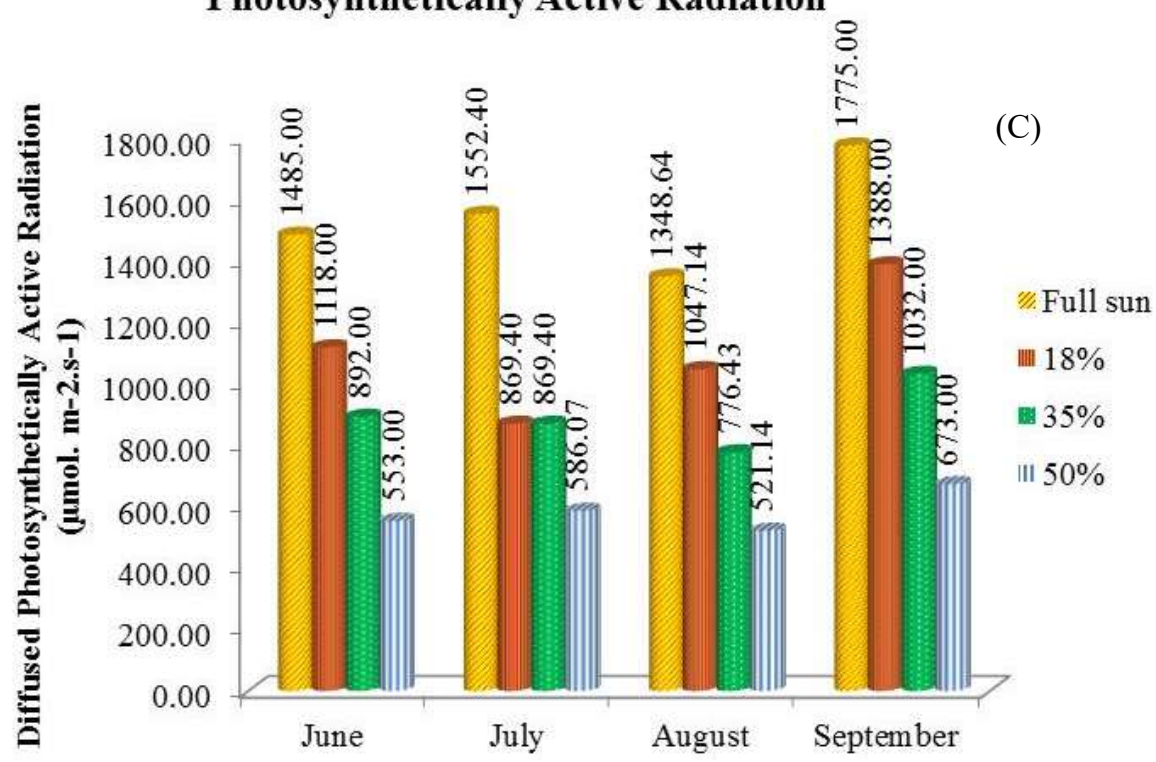

FIGURE 1. Air temperature (a), Relative air humidity (b), and photosynthetically active radiation (PAR) (c) recorded at full sun and in the growing environments during the experimental period.

TABLE 4. Means of temperature $\left({ }^{\circ} \mathrm{C}\right)$, relative air humidity $(\%)$, and diffuse active solar radiation $\left(\mu \mathrm{mol} \mathrm{m}^{-2} \mathrm{~s}^{-1}\right)$. Cassilândia, MS, July-September 2016.

\begin{tabular}{lcccc}
\hline Micrometeorological variable & Full sun & $18 \%$ & $35 \%$ & $50 \%$ \\
\hline Temperature $\left({ }^{\circ} \mathrm{C}\right)$ & 24.5 & 24.2 & 24.1 & 24.0 \\
Relative air humidity $(\%)$ & 72.0 & 71.2 & 69.8 & 71.7 \\
Photosynthetically active radiation $\left(\mu \mathrm{mol} \mathrm{m}^{-2} \mathrm{~s}^{-1}\right)(\mathrm{PAR})$ & 1540.3 & 1105.6 & 892.5 & 583.3 \\
Percentage of PAR $(\%)$ & 100.0 & 71.8 & 57.9 & 37.9 \\
\hline
\end{tabular}

The relationship between the highest and lowest mean-squared residuals from the analysis of substrate (RMSR) in the three shading levels showed an index below 7 for all variables, i.e., it allowed performing the analysis of the group of experiments (Banzatto \& Kronka, 2013) and comparison between environments (Table 5). 
TABLE 5. Relationship between the highest and lowest mean-squared residuals from the analysis of substrate (RMSR) for emergence speed index (ESI), percentage of emergence (PE), plant height at 45 (PH1), 52 (PH2), 59 (PH3), and 66 (PH4) DAS, collar diameter (CD), shoot dry matter (SDM), root dry matter (RDM), total dry matter (TDM), the shoot to root system dry matter ratio (SRR), and the Dickson quality index (DQI) of papaya seedlings in different environments and substrates. Cassilândia, MS, 2016.

\begin{tabular}{|c|c|c|c|c|c|c|}
\hline Shading & ESI & PE $(\%)$ & PH1 (cm) & $\mathrm{PH} 2(\mathrm{~cm})$ & PH3 (cm) & $\mathrm{PH} 4(\mathrm{~cm})$ \\
\hline $18 \%$ & 0.0018 & 0.060 & 0.417 & 1.122 & 2.329 & 8.959 \\
\hline $35 \%$ & 0.0012 & 0.040 & 0.358 & 1.132 & 1.055 & 7.628 \\
\hline $50 \%$ & 0.0034 & 0.066 & 0.302 & 0.762 & 1.139 & 6.196 \\
\hline RMSR & 2.74 & 1.66 & 1.38 & 1.49 & 2.21 & 1.45 \\
\hline Shading & $\mathrm{CD}(\mathrm{mm})$ & $\mathrm{SDM}(\mathrm{g})$ & RDM (g) & TDM (g) & SRR & DQI \\
\hline $18 \%$ & 0.707 & 0.112 & 0.016 & 0.207 & 0.050 & 0.0069 \\
\hline $35 \%$ & 0.420 & 0.111 & 0.012 & 0.183 & 0.182 & 0.0036 \\
\hline $50 \%$ & 0.432 & 0.064 & 0.003 & 0.086 & 0.218 & 0.0017 \\
\hline RMSR & 1.68 & 1.75 & 4.66 & 2.41 & 4.35 & 4.07 \\
\hline
\end{tabular}

Substrate S4 stood out in relation to the others as it provided adequate conditions to obtain the best ESI and PE under the three shading levels (Table 6). This substrate did not present in its constitution cattle manure. Costa et al. (2016) evaluated the initial performance of papaya on substrates with different compositions of tanned cattle manure by analyzing mean germination rate and speed index and did not observe substrate composition influence on the early development of papaya seedlings.

These results show that during seedling germination and emergence, seed reserves are responsible for supplying assimilates. Thus, during initial development, there is no need for organic matter in the soil but a proper physical structure. It is in agreement with Oliveira et al. (2014), who observed that inert materials that compose the physical components are important during the emergence process of Dipteryx alata, with a higher percentage of emergence in substrates with lower amounts of cattle manure.

The substrate S3 provided papaya seedlings with the highest height during evaluations carried out at 45, 52, 59 , and 66 days after sowing (DAS) under 18\% shading. On the other hand, the highest plant heights under the $50 \%$ shading environment were observed in the substrates S3 and $\mathrm{S} 4$, while the $35 \%$ shading environment presented the highest values at 45 DAS in the substrates S1, S2, and S4. However, seedlings did not differ in height as a function of the substrate at 66 DAS (Table 6).

In general, all substrates promoted an adequate growth in height, including those containing lower and higher cattle manure contents (Table 6). Substrates with a lower content of cattle manure promoted adequate growth since they presented a higher amount of hillside soil, which is a type of soil with high availability nutrients and organic matter, thus ensuring nutritional supply to the growth of papaya seedlings. According to Melo et al. (2007), substrates with the lowest percentages of organic matter from manure allowed producing papaya seedlings with higher heights and diameters, corroborating the result obtained in this study. 
TABLE 6. Emergence speed index (ESI), percentage of emergence (PE), plant height at 45 (PH1), 52 (PH2), 59 (PH3), and 66 (PH4) DAS of papaya seedlings at different environments and substrates. Cassilândia, MS, 2016.

\begin{tabular}{lccc}
\hline & \multicolumn{2}{c}{ Shading level (environment) } \\
\hline & $18 \%$ & $35 \%$ & $50 \%$ \\
S1 & $0.24 \mathrm{bB}$ & Emergence speed index (ESI) & $0.21 \mathrm{bC}$ \\
S2 & $0.28 \mathrm{Ab}$ & $0.30 \mathrm{aB}$ & $0.28 \mathrm{aB}$ \\
S3 & $0.38 \mathrm{aA}$ & $0.31 \mathrm{aB}$ & $0.38 \mathrm{aA}$ \\
S4 & $0.33 \mathrm{aA}$ & $0.21 \mathrm{bC}$ & $0.34 \mathrm{aA}$ \\
CV $(\%)$ & & $0.38 \mathrm{aA}$ & \\
SD & & 15.31 & 0.0465 \\
\hline
\end{tabular}

\begin{tabular}{lccr}
\hline & $*$ Percentage of emergence $(\mathrm{PE}, \%)$ in the stabilization of the faster treatment \\
S1 & $1.13 \mathrm{aA}$ & $1.25 \mathrm{aA}$ & $0.89 \mathrm{aB}$ \\
S2 & $1.29 \mathrm{aA}$ & $1.38 \mathrm{aA}$ & $1.26 \mathrm{aA}$ \\
S3 & $1.38 \mathrm{aA}$ & $0.88 \mathrm{bB}$ & $1.49 \mathrm{aA}$ \\
S4 & $1.48 \mathrm{aA}$ & $1.57 \mathrm{aA}$ & $1.20 \mathrm{bA}$ \\
CV $(\%)$ & & 18.53 & \\
SD & & 0.2351 &
\end{tabular}

\begin{tabular}{|c|c|c|c|}
\hline \multirow[b]{2}{*}{ S1 } & \multicolumn{3}{|c|}{ Plant height (PH1) at 45 DAS $(\mathrm{cm})$} \\
\hline & $6.24 \mathrm{aB}$ & $6.40 \mathrm{aA}$ & $4.34 \mathrm{bC}$ \\
\hline S2 & $5.38 \mathrm{bB}$ & $6.62 \mathrm{aA}$ & $6.38 \mathrm{aB}$ \\
\hline S3 & $7.40 \mathrm{aA}$ & $5.58 \mathrm{bB}$ & $7.90 \mathrm{aA}$ \\
\hline $\mathrm{S} 4$ & $5.94 \mathrm{cB}$ & $6.82 \mathrm{bA}$ & $8.12 \mathrm{aA}$ \\
\hline $\mathrm{CV}(\%)$ & & 9.32 & \\
\hline SD & & 0.5989 & \\
\hline
\end{tabular}

\begin{tabular}{|c|c|c|c|}
\hline \multicolumn{4}{|c|}{ Plant height (PH2) at 52 DAS (cm) } \\
\hline $\mathrm{S} 1$ & $8.30 \mathrm{aB}$ & $9.20 \mathrm{aA}$ & $5.70 \mathrm{bC}$ \\
\hline $\mathrm{S} 2$ & $7.02 \mathrm{bB}$ & $9.82 \mathrm{aA}$ & $9.38 \mathrm{aB}$ \\
\hline S3 & $10.20 \mathrm{bA}$ & $7.88 \mathrm{cB}$ & $11.52 \mathrm{aA}$ \\
\hline S4 & $8.18 \mathrm{cB}$ & $10.28 \mathrm{aB}$ & $11.72 \mathrm{aA}$ \\
\hline $\mathrm{CV}(\%)$ & & 11.02 & \\
\hline SD & & 1.0020 & \\
\hline
\end{tabular}

\begin{tabular}{|c|c|c|c|}
\hline \multirow[b]{2}{*}{ S1 } & \multicolumn{3}{|c|}{ Plant height (PH3) at 59 DAS (cm) } \\
\hline & $11.38 \mathrm{aB}$ & $12.22 \mathrm{aB}$ & $8.58 \mathrm{bC}$ \\
\hline $\mathrm{S} 2$ & $9.88 \mathrm{bB}$ & $13.72 \mathrm{aA}$ & $13.06 \mathrm{aB}$ \\
\hline S3 & $13.88 \mathrm{bA}$ & $9.38 \mathrm{cC}$ & $16.20 \mathrm{aA}$ \\
\hline S4 & $11.30 \mathrm{cB}$ & $14.10 \mathrm{bA}$ & $17.00 \mathrm{aA}$ \\
\hline CV $(\%)$ & \multicolumn{3}{|c|}{9.78} \\
\hline SD & \multicolumn{3}{|c|}{1.2282} \\
\hline
\end{tabular}

\begin{tabular}{|c|c|c|c|}
\hline \multicolumn{4}{|c|}{ Plant height (PH4) at 66 DAS (cm) } \\
\hline $\mathrm{S} 1$ & $17.30 \mathrm{bB}$ & $21.00 \mathrm{aA}$ & $15.42 \mathrm{bC}$ \\
\hline $\mathrm{S} 2$ & $17.38 \mathrm{aB}$ & $20.72 \mathrm{aA}$ & $20.18 \mathrm{aB}$ \\
\hline $\mathrm{S} 3$ & $22.26 \mathrm{aA}$ & $18.74 \mathrm{bA}$ & $24.64 \mathrm{aA}$ \\
\hline $\mathrm{S} 4$ & $17.70 \mathrm{bB}$ & $20.52 \mathrm{bA}$ & $24.60 \mathrm{aA}$ \\
\hline $\mathrm{CV}(\%)$ & & 13.75 & \\
\hline $\mathrm{SD}$ & & 2.7552 & \\
\hline
\end{tabular}


Seedlings exposed to the environment with $18 \%$ shading and substrate S3 presented the highest collar diameters, but with no differences between substrates in the $35 \%$ shading environment, while in the $50 \%$ shading environment, the highest diameters were observed in seedlings conducted in the substrates $\mathrm{S} 3$ and S4. The environment with $18 \%$ shading allowed the development of seedlings with a higher collar diameter for all evaluated substrates (Table 7).

Papaya seedling production under protected environments promoted a higher increase in the analyzed growth parameters when compared to the environment at the full sun, which was detrimental to papaya seedlings because plants at full sun were exposed to weather conditions. Environments with 18 and 35\% shading stood out among those promoted by screens because they formed high-quality seedlings. These environments presented means of PAR ranging from 890 to $1100 \mu \mathrm{mol} \mathrm{m}^{-2} \mathrm{~s}^{-1}$ during the study period, i.e., from June to September (Figure $1 \mathrm{C}$ and Table 4), determining a possible radiation range appropriate to seedling growth.

Substrates did not differ from each other in the $35 \%$ shading environment regarding shoot dry matter (SDM) and total dry matter (TDM). Moreover, substrate S3 in the $18 \%$ shading environment, as well as substrates S3 and S4 in the $50 \%$ shading environment, promoted seedling formation with better values of SDM and TDM (Table 7). The comparison between shading levels for SDM showed no differences for substrates S1, S2, and S3, while the best environment for S4 was 50\% shading. In addition, TDM showed no statistical difference between environments for all evaluated substrates.

TABLE 7. Collar diameter (CD), shoot dry matter (SDM), total dry matter (TDM), and shoot to root system dry matter ratio (SRR) of papaya seedlings under different environments and substrates. Cassilândia, MS, 2016.

\begin{tabular}{lccc}
\hline \multicolumn{4}{c}{ Shading level (environment) } \\
\hline & $18 \%$ & $35 \%$ & $50 \%$ \\
\hline S1 & & Collar diameter (CD) (mm) & $4.10 \mathrm{bB}$ \\
S2 & $5.32 \mathrm{aB}$ & $5.21 \mathrm{aA}$ & $4.51 \mathrm{aB}$ \\
S3 & $4.95 \mathrm{aB}$ & $5.25 \mathrm{aA}$ & $6.06 \mathrm{bA}$ \\
S4 & $7.02 \mathrm{aA}$ & $4.54 \mathrm{cA}$ & $6.18 \mathrm{aA}$ \\
CV $(\%)$ & $5.41 \mathrm{aB}$ & $5.88 \mathrm{aA}$ & \\
SD & & 13.42 & \\
\hline
\end{tabular}

\begin{tabular}{lccc}
\hline & & Shoot dry matter (SDM) (g) \\
S1 & $1.11 \mathrm{aB}$ & $1.42 \mathrm{aA}$ & $1.00 \mathrm{aB}$ \\
S2 & $1.37 \mathrm{aB}$ & $1.35 \mathrm{aA}$ & $1.09 \mathrm{aB}$ \\
S3 & $1.71 \mathrm{aA}$ & $1.25 \mathrm{aA}$ & $1.41 \mathrm{aA}$ \\
S4 & $1.20 \mathrm{bB}$ & $1.32 \mathrm{bA}$ & $1.67 \mathrm{aA}$ \\
CV $(\%)$ & & 23.24 & \\
SD & & 0.3091 &
\end{tabular}

\begin{tabular}{lccr}
\hline & & Total dry matter (TDM) $(\mathrm{g})$ & \\
S1 & $1.52 \mathrm{aB}$ & $1.83 \mathrm{aA}$ & $1.28 \mathrm{aB}$ \\
S2 & $1.82 \mathrm{aB}$ & $1.83 \mathrm{aA}$ & $1.41 \mathrm{aB}$ \\
S3 & $2.32 \mathrm{aA}$ & $1.78 \mathrm{aA}$ & $1.86 \mathrm{aA}$ \\
S4 & $1.78 \mathrm{aB}$ & $1.91 \mathrm{aA}$ & $2.29 \mathrm{aA}$ \\
CV $(\%)$ & & 22.09 & \\
SD & & 0.3986 & \\
\hline
\end{tabular}

\begin{tabular}{lccc}
\hline & & Shoot to root system dry matter ratio (SRR) & \\
S1 & $2.77 \mathrm{bA}$ & $3.51 \mathrm{aA}$ & $3.62 \mathrm{aA}$ \\
S2 & $3.07 \mathrm{bA}$ & $2.84 \mathrm{bB}$ & $3.49 \mathrm{aA}$ \\
S3 & $2.86 \mathrm{aA}$ & $2.39 \mathrm{bC}$ & $3.16 \mathrm{aB}$ \\
S4 & $2.06 \mathrm{bB}$ & $2.27 \mathrm{bC}$ & $2.72 \mathrm{aB}$ \\
CV (\%) & & 21.02 & \\
SD & & 0.3877 &
\end{tabular}

Means followed by the same uppercase letter in the columns and lowercase letter in the rows for each parameter do not differ from each other by the Scott Knott test at 5\% probability. CV = coefficient of variation; $\mathrm{SD}=$ standard deviation; $\mathrm{S} 1=0 \% \mathrm{HS}$ $+45 \% \mathrm{CM}+20 \% \mathrm{BP}+20 \% \mathrm{FS}+15 \% \mathrm{FV} ; \mathrm{S} 2=15 \% \mathrm{HS}+30 \% \mathrm{CM}+20 \% \mathrm{BP}+20 \% \mathrm{FS}+15 \% \mathrm{FV} ; \mathrm{S} 3=30 \% \mathrm{HS}+15 \%$ $\mathrm{CM}+20 \% \mathrm{BP}+20 \% \mathrm{FS}+15 \% \mathrm{FV} ; \mathrm{S} 4=45 \% \mathrm{HS}+0 \% \mathrm{CM}+20 \% \mathrm{BP}+20 \% \mathrm{FS}+15 \% \mathrm{FV} ; \mathrm{HS}=$ hillside soil; $\mathrm{CM}=$ cattle manure; $\mathrm{BP}=$ Bioplant $^{\mathbb{B}} ; \mathrm{FS}=$ washed fine sand; $\mathrm{FV}=$ super fine-grained vermiculite. 
Although all substrates had the same amount of vermiculite in their composition, this material contributed to providing favorable conditions for seedling development. In this sense, according to Costa et al. (2009), substrates containing vermiculite in their composition promoted higher biomass accumulation in papaya seedlings because this material provides higher porous space, high aeration capacity and, consequently, better water retention, thus explaining the higher dry matter accumulation in seedlings.

Substrates S3 and S4, which had higher amounts of hillside soil, presented a lower shoot to root system dry matter ratio (SRR), i.e., higher root distribution. Regarding the environments, the lowest ratios occurred in environments with the lowest solar radiation under 18 and $35 \%$ shading levels (Figure 1 and Table 7).

The variables root dry matter (RDM) and Dickson quality index (DQI) showed no interaction between shading factors and substrates. The 18 and $35 \%$ shading environments formed seedlings with higher values of RDM and DQI. Substrates S3 and S4, which presented manure contents below $15 \%$, formed seedlings with higher values of RDM and DQI (Table 8).
It shows that papaya had better growth when PAR

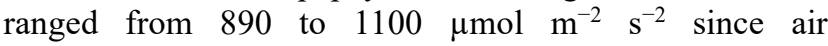
temperatures and relative air humidity were similar in all study environments (Figures 1A, 1B, and 1C and Table 4). Salles et al. (2017) studied formation of black plum and papaya seedlings in Cassilândia - MS (Brazil) and found the highest Dickson quality indices, diameters, shoot dry matter, and total dry matter under 18 and $35 \%$ shading.

In studies with papaya seedling production on different substrates, Melo et al. (2007) reported that the highest phytomass accumulation in the root system occurred in substrates with lower manure contents, and that substrates with good physical condition provided higher porosity and aeration, thus promoting ideal conditions for root growth, corroborating the results found in this experiment.

Substrates with lower manure contents (S3 and S4) promoted seedling formation with higher phytomass of root system, height, diameters, and DQI, characterizing good quality seedlings. Seedlings with a higher root system have a better growth trend in the field after transplantation.

TABLE 8. Root dry matter (RDM) and Dickson quality index (DQI) of papaya seedlings under different environments and substrates. Cassilândia, MS, 2016.

\begin{tabular}{|c|c|c|}
\hline Environment & RDM (g) & DQI \\
\hline $18 \%$ shading & $0.51 \mathrm{~A}$ & $0.31 \mathrm{~A}$ \\
\hline $35 \%$ shading & $0.50 \mathrm{~A}$ & $0.28 \mathrm{~A}$ \\
\hline $50 \%$ shading & $0.41 \mathrm{~B}$ & $0.23 \mathrm{~B}$ \\
\hline Substrate & $\operatorname{MSSR}(\mathrm{g})$ & IQD \\
\hline $\mathrm{S} 1=0 \% \mathrm{HS}+45 \% \mathrm{CM}+20 \% \mathrm{BP}+20 \% \mathrm{FS}+15 \% \mathrm{FV}$ & $0.36 \mathrm{~B}$ & $0.22 \mathrm{~B}$ \\
\hline $\mathrm{S} 2=15 \% \mathrm{HS}+30 \% \mathrm{CM}+20 \% \mathrm{BP}+20 \% \mathrm{FS}+15 \% \mathrm{FV}$ & $0.41 \mathrm{~B}$ & $0.24 \mathrm{~B}$ \\
\hline $\mathrm{S} 3=30 \% \mathrm{HS}+15 \% \mathrm{CM}+20 \% \mathrm{BP}+20 \% \mathrm{FS}+15 \% \mathrm{FV}$ & $0.52 \mathrm{~A}$ & $0.31 \mathrm{~A}$ \\
\hline $\mathrm{S} 4=45 \% \mathrm{HS}+0 \% \mathrm{CM}+20 \% \mathrm{BP}+20 \% \mathrm{FS}+15 \% \mathrm{FV}$ & $0.59 \mathrm{~A}$ & $0.34 \mathrm{~A}$ \\
\hline $\mathrm{CV}(\%)$ & 21.57 & 23.02 \\
\hline SD & 0.1023 & 0.0637 \\
\hline
\end{tabular}

Means followed by the same letter in the column for each parameter do not differ from each other by the Scott Knott test at $5 \%$ probability. $\mathrm{CV}=$ coefficient of variation; $\mathrm{SD}=$ standard deviation.

\section{CONCLUSIONS}

Substrates with a higher amount of hillside soil and lower contents of cattle manure formed high-quality seedlings. The most outstanding substrate composition consisted of $30 \%$ hillside soil $+15 \%$ cattle manure $+20 \%$ Bioplant $^{\circledR}+20 \%$ washed fine sand $+15 \%$ super finegrained vermiculite and $45 \%$ hillside soil $+0 \%$ cattle manure + Bioplant $^{\circledR}+20 \%$ washed fine sand $+15 \%$ super fine-grained vermiculite.

Shaded environments are essential for papaya seedling formation, mainly between 18 or $35 \%$ shading.

\section{ACKNOWLEDGMENTS}

To the Fundação de Apoio ao Desenvolvimento do Ensino, Ciência e Tecnologia of the State of Mato Grosso do Sul (FUNDECT/PRONEM/PPP), to the Conselho
Nacional de Desenvolvimento Científico e Tecnológico (CNPq) for granting scientific initiation scholarship, and to the Coordenação de Aperfeiçoamento de Pessoal de Nível Superior (CAPES) for granting masters scholarship.

\section{REFERENCES}

Albano FG, Marques AS, Cavalcante IHL (2014)

Substrato alternativo para produção de mudas de mamoeiro formosa (cv. Caliman). Revista Científica 42(4):388-395.

Arrua LC, Costa E, Bardiviesso EM, Nascimento DM, Binotti FFS (2016) Protected environments and substrates for mangabeira seedlings (Hancornia speciosa gomez) production. Engenharia Agrícola 36(6):984-995.

Banzatto DA, Kronka SN (2013) Experimentação agrícola. Jaboticabal, Funep, 237 p. 
Costa E, Leal PAM, Santos LCR, Vieira LCR (2010a)

Crescimento de mudas de mamoeiro conduzidas em diferentes ambientes protegidos, recipientes e substratos na região de Aquidauana, Estado do Mato Grosso do Sul. Acta Scientiarum. Agronomy 32(3):463-470.

Costa E, Mesquita VAG, Leal PAM, Fernandes CD, Abot AR (2010b) Formação de mudas de mamão em ambientes de cultivo protegido em diferentes substratos. Revista Ceres 57(5):679-685.

Costa E, Santos LCR, Vieira LCR (2009) Produção de mudas de mamoeiro utilizando diferentes substratos, ambientes de cultivo e recipientes. Engenharia agrícola 29(4):528-537.

Costa FCL, Silveira ATL, Nogueira FHM, Sotero ARH, Deus MVC, Uchôa CN (2016) Desempenho inicial de mamoeiro em diversos substratos. Revista Internacional de Ciências 6(2):191-198.

Costa E, Dias JG, Lopes KG, Binotti FFS, Cardoso ED (2015) Telas de Sombreamento e Substratos na Produção de Mudas de Dipteryx alata Vog. Revista floresta e ambiente 22(3):416-425.
Melo AS, Costa CX, Brito MEB, Viégas PRA, Silva Júnior CD (2007) Produção de mudas de mamoeiro em diferentes substratos e doses de fósforo. Revista Brasileira de Ciências Agrárias 2(4):257-261.

Oliveira LC, Costa E, Oliveira AD, Jorge MHA (2014) Emergência do baruzeiro sob ambientes protegidos e substratos. Revista de Agricultura Neotropical 1(1):10-16.

Pereira TA, Silva SS, Andrade EMG, Costa JPM, Soares PCE, Oliveira FS, Maracajá PB (2015) Produção de mudas de mamoeiro em diferentes substratos. Agropecuária Científica no Semi-Árido 11(2):86-98.

Salles JS, Lima AHF, Costa E (2017) Mudas de jambolão sob níveis de sombreamento, bancadas refletoras e profundidade de semeadura. Revista de Agricultura Neotropical 4(supl1):110-118.

Sanches CF, Costa E, Costa GGS, Binotti FFS, Cardoso ED (2017) Mudas de Hymenaea coubaril em ambientes protegidos e substratos. Engenharia Agrícola 37(1):24-34.

Silva EA, Maruyama WI, Mendonça V, Francisco MGS, Bardiviesso DM, Tosta MS (2010) Composição de substratos e tamanho de recipientes na produção e qualidade das mudas de maracujazeiro 'amarelo'. Ciência e agrotecnologia 34(3):588-595. 